\title{
RHODESIAN ANTHRAX: THE USE OF BACTERIOLOGICAL \& CHEMICAL AGENTS DURING THE LIBERATION WAR OF 1965-80
}

\author{
Ian Martinez*
}

\begin{abstract}
In 1979, the largest recorded outbreak of anthrax occurred in Rhodesia, present day Zimbabwe. The incident, widely known in Africa and in intelligence circles is not widely known in the U.S. or Europe. At the time, Rhodesia was fighting a guerilla war against black nationalist insurgents. Rhodesia first accused the nationalist side of using anthrax as a weapon. In allegations that surfaced in 1998-and persist to this day-external researchers and the current government of Zimbabwe insist that the outbreak in 1978-80 was anything but benign. The government and researchers argue that the original outbreak was the result of a calculated move by the Rhodesian government with the duplicitous acknowledgment of Apartheid South Africa. Furthermore, the government alleges that a current outbreak is the work of disgruntled white farmers in the country. The allegations of the 1979-80 outbreak are given credence by the acknowledgement of Ken Flower, Chief of Rhodesia's Central Intelligence Organization, ("CIO") and CIO Officer, Henrik Ellert, that the white minority regime of Ian Smith used biological and chemical weapons against the guerillas, rural blacks to prevent their support of the guerillas and against cattle to reduce rural food stocks. The current government and researchers have drawn inferences from his statements to show that the unusual outbreak in 1978-80 was a deliberate use of weaponized anthrax. These inferences rely on important aspects which will be highlighted in this paper, mainly: a) by 1978 the 'writing was on the wall' for the white regime and resort to a weapon of last resort was not unfathomable; $b$ ) because of its international status, Rhodesia
\end{abstract}

* Ian Martinez, is an attorney with Rasco Reininger Perez \& Esquenazi, P.L. in Miami. $\mathrm{He}$ is a former CIA Intelligence Officer who has written several articles dealing with international law. I wish to thank the Editorial staff of the Review, which worked tirelessly to bring this article forward. I dedicate this article to the thousands of Zimbabweans, both black and white, who suffered needlessly during the war and continue to suffer. 
had become an expert in sanctions busting; c) the alliance between South Africa and Rhodesia make the allegations more credible; and d) the current government of Zimbabwe has purposefully failed to launch a formal investigation because it is convenient to its continued survival to vilify the former regime and current white farmers in order to deflect attention away from the twenty-one year old dictatorship of Robert Mugabe and the economic woes that have followed from the regime's mismanagement.

\section{HISTORICAL SETTING}

On September 12,1890, a pioneer settler column' arrived in present-day Harare-formerly Salisbury-under the auspices of Cecil Rhodes British South African Company (BSAC). ${ }^{2}$ The area was thought to be rife with gold deposits and was said to be the ancient site of King Solomon's mines. ${ }^{3}$ Through a treaty with the King of the Matabeles, the BSAC was responsible for administration of the territory. ${ }^{4}$ In 1893, the Ndebele-another ethnic group-took up arms against the colonizers, but were swiftly defeated in the Matabele War. ${ }^{5}$ In 1896, the Ndebele, joined by the Shona, rose again in rebellion against the pioneers. ${ }^{6}$ The Chimurenga $\mathrm{War}^{7}$-as the indigenous groups called the war-was brutally suppressed by the Rhodesians by $1897 .^{8}$

1. See Thomas Packenham, The SCRamble for Africa 1876-1912, 372-73 (1991). The pioneers consisted of not a single woman, but of 200 raw recruits, 500 police of the British South Africa Company (BSAC), plus hundreds of African porters. See id. at 372-73. See also ANTHONY THOMAS, RHODES 218 (1996) (describing the force as an 'army' and the 200 men with uniforms of "brown tunics, yellow leathering leggings, and bush hats. Each man carried a Martini-Henry rifle and a revolver.").

2. See PACKENHAM, supra note 1 , at 373.

3. See THOMAS, supra note 1 , at 134 .

4. See id. at 197. The new territory was to be run by the BSAC, a chartered company. No one told King Lobengula that the purpose of the treaty, and the company, was "to nun the government, levy taxes, maintain a police force and when necessary, try a man for his life." Id.

5. See PETER ABBOTT \& PHILIP BOTHAM, MODERN AFRICAN WARS (I): RHODESIA 1965803 (1986); see also THOMAS, supra note 1, at 246-60; see also PACKENHAM, supra note 1, at 492-95. 306-21.

6. See PACKENHAM, supra note 1 , at 498-02. See generally THOMAS, supra note 1 , at

7. See ABBOTT \& BoTHAM, supra note 5, at 4. "Chimurenga means 'uprising' or 'resistance' in Chishona." ROY NESBIT \& DUDLEY COWDEROY, BRITAIN's REBEL AIR FORCE: THE WAR FROM THE AIR IN RHODESIA, 1965-1980 33 (1998).

8. See CBC News, Zimbabwe Land, at http://cbc.ca/news/indepth/zimbabawe/ history.html (last visited Feb. 13, 2003). 


\section{A. Self-government}

Immediately after World War I, the British Empire was undergoing a dramatic internal realignment. ${ }^{9}$ By 1918 , the white-majority dominions of Canada, New Zealand, and Australia were internally self-governed, with the major limitation being lack of control over their international relations. ${ }^{10}$ South Africa's white minority was given the same status. ${ }^{11}$ An election was held in 1922, to determine Rhodesia's standing within the Empire. ${ }^{12}$ The choice was between entry into the Union of South Africa, as its fifth province, or full internal self-government. ${ }^{13}$ The Rhodesians opted for self-government. ${ }^{14}$ On Sept. 12, 1923, "Southern Rhodesia" was annexed to the crown and became a self-governing colony, a de facto Dominion. ${ }^{\text {Is }}$ The British government retained control of external affairs and a final veto with respect to legislation directly affecting Africans. ${ }^{16}$

\section{B. The Roots of UDI: Dominion Status or Federation}

Having governed Southern Rhodesia successfully for twenty-four years and having paid a disproportionately high price in human life during World War II, ${ }^{17}$ the whites believed that they had earned formal Dominion status. "They were blissfully unaware that Britain was bent on retreating from the Empire and not on acquiring another white-led Dominion."18 The Southern Rhodesians had essentially three choices: 1) "join South Africa but this had been rejected in 1922 and few still advocated it;" ${ }^{19}$ 2) seek dominion status; or

9. See generally P.J. MARSHALL, CAMBRIDGE ILlUSTRATED HISTORY OF THE BRITISH EMPIRE 96-97 (1996).

10. See id.

11. See id. at 96.

12. See HARDWICKE HOLDERNESS, LOST CHANCE: SOUTHERN RHODESIA 1945-1958 19 (1985).

13. See id.

14. See Alan Best \& HaRm DE BLIJ, AfRICAN SURVEY 295 (1977). The vote was 8774 to 5989 in favor of self-rule. Id.

15. See NESBIT \& COWDEROY, supra note 7, at 6 . "The limited powers reserved to the British government in 1923 had never been invoked. It seemed that these powers had been ceded by default and could thus be forgotten, so that a de facto Dominion status was in being." Id.

16. See MARSHALL, supra note 9 , at 97.

17. See NESBIT \& COWDEROY, supra note 7, at 11. For example, the future Prime Minister Ian Smith was shot down twice in the war. See id. at 8-9. This military tradition may be one reason Rhodesians were ready for a military conflict in 1965 .

18. J.T.R. Wood, Rhodesian Insurgency, at http://www.rhodesia.myweb.nl/rhomil.htm (last visited Nov. 10,2001) [hereinafter Rhodesian Insurgency]; see also MARSHALL, supra note 9, at 101 .

19. Rhodesian Insurgency, supra note 18 . The Afrikaner National Party won the 1948 elections, plunging South Africa into the apartheid abyss. See id. For a detailed explanation of the development of the South African legal system in the early twentieth century, which codified Apartheid in 1948, see MARTIN CHANOCK, THE MAKING OF SOUTH AFRICAN LEGAL 
3) federate with Northern Rhodesia (present day Zambia) and Nyasaland (present day Malawi) creating a new British dominion. ${ }^{20}$

Furthermore, there was an idealism in Britain that Southern Rhodesia could help to develop both Northern Rhodesia and Nyasaland, and that whites and blacks could live and work together in a partnership. ${ }^{21}$ In 1953, amidst much enthusiasm, the Central African Federation was born. ${ }^{22}$ "The most crucial area of administration, that of the African affairs, was left in territorial hands because Britain would not relinquish her role as protector. This meant that Northern Rhodesian and Nyasaland Africans were ultimately ruled by London and Southern Rhodesian Africans by Salisbury."23 The black population revolted and began guerilla activities aimed at eventual independence in Nyasaland and Northern Rhodesia. ${ }^{24}$ The revolt signaled the death knell of the Federation. ${ }^{25}$

\section{Southern Rhodesia and Independence -The Growth of African Nationalism}

In 1962, Nyasaland (the least developed territory of the Federation) was allowed to secede, even though constitutionally this was forbidden. ${ }^{26}$ "Northern Rhodesia's secession terminated the Federation's short life on 31 December 1963."27 Nonetheless, the tide of black majority rule was stopped by Southern Rhodesia. Whites from the Congo, Nyasaland, and Northern Rhodesia streamed into Southern Rhodesia as refugees, and strengthened the resolve of the white minority. ${ }^{28}$ The new line dividing controlled areas from independent black Africa was drawn from Portuguese Angola, across Rhodesia, and on to Portuguese controlled Mozambique. The southern flank was anchored by apartheid South Africa.

With the dissolution of the Federation, Southern Rhodesia wanted independence. ${ }^{29}$ According to Ian Smith, the British government had promised

CULTURE: 1902-1936 (2001).

20. See Rhodesian Insurgency, supra note 18.

21. See MARSHALl, supra note 9, at 101. See also NeSBIT \& COWDEROY, supra note 7, at 15. All three territories were ruled by a white minority. See id. From a purely economic standpoint the Federation made sense; however, from a practical stand point the theory of colonialzation was maintained. See id.

22. See MARSHALL, supra note 9 , at 101 . The Federation was approved by a referendum vote in Southern Rhodesia, and mandated by London in Northern Rhodesia and Nyasaland. See HOLDERNESS, supra note 12, at 122.

23. Rhodesian Insurgency, supra note 18.

24. See HOLDERNESS, supra note 12, at 230.

25. See id.

26. Rhodesian Insurgency, supra note 18.

27. Id.

28. See NESBIT \& COWDEROY, supra note 7, at 19. See also GRAHAM Boynton, LAST DAYS IN ClOUd CuCKOOLAND: DisPatCHES FROM WHITE AFRICA 33 (1997).

29. See MARSHALL, supra note 9, at 101. 
the Rhodesians their independence before the Federation, "[W]e can have our dominion status tomorrow ... a after our exemplary record, it is there for the asking." 30 Yet, Britain was unwilling to grant Southern Rhodesian independence. ${ }^{31}$ The vulnerability of the white regime could be tasted from within the reserves - the hitherto places of imposed internal exile-they quickly became the battleground of the insurgency. ${ }^{32}$

\section{The Road to UDI}

"Copying their Nyasaland and Northern Rhodesian counterparts, the Southern Rhodesian African nationalists in 1956 adopted a new militancy ...."33 In 1959, the National Democratic Party (NDP)-a nationalist black party-demanded total emancipation. "In mid-1960, the NDP's demands for power provoked violence in Salisbury and Bulawayo and the arrest of its leaders." 34

[The] violence in October 1960 was serious enough for the police to lose their enviable record of not having killed anyone in the course of their duties that century. Seven Africans died in prolonged unrest .... More disorder provoked [the banning of the] NDP in December, whereupon, Nkomo created the Zimbabwe African People's Union (ZAPU) pledged to secure majority rule. ${ }^{35}$

As early as 1956, the security forces, including the police, recognized that the major problem confronting them would be African unrest. ${ }^{36}$ "Thus the security forces trained and prepared for counter-insurgency at home, as well as reinforcing British efforts in Malaya and studying the counter-insurgency effort against the Mau Mau in Kenya."37 In 1950, Rhodesia created its own Special Air Service (SAS) and sent the team to Malaya to help the British fight a Communist insurgency there. ${ }^{38}$ The SAS became the backbone of Rhodesia's special operations team. "The Army devoted half its training to counter-insurgency, while the Air Force formed a counter-insurgency squadron. Because insurgency essentially challenges the law, the police took

30. Ian Douglas Smith, The Great Betrayal 32 (1997).

31. See BEST \& BLIJ, supra note 14, at 297.

32. See Rhodesian Insurgency, supra note 18.

33. Id.

34. Id.

35. $l d$.

36. $l d$.

37. See id.

38. See AвBотт \& Bотнам, supra note 5, at 18. 
the lead with the military in support. Thus the counter-insurgency campaign began on a low key, led by the (BSAP)." ${ }^{39}$

In early September 1962, the Zimbabwe Liberation Army proclaimed the Zimbabwe Revolution resulting in an outbreak of sabotage and arson. ${ }^{40}$ The government "banned ZAPU and declared that it would not be allowed to reappear in another guise... There followed detentions, police raids and the first uncovering of stocks of explosives and weapons, including sub-machine guns and hand-guns. 1,094 persons were arrested." "41 "[ ] ]n 1963, a resurgence of urban violence had been quelled by mandatory death sentences for petrol bombing." ${ }^{42}$ The Zimbabwe African National Union (ZANLA, the military wing of ZANU) dispatched young men for guerrilla training in China. ${ }^{43}$ The first of the terror killings was in July $1964 .^{44}$

With the indigenous Africans increasingly in rebellion, Ian Smith, the most prominent hard-liner, rose to power within the Rhodesian Front (RF). ${ }^{45}$ In December 1962, the RF, led by Smith, won the general elections. Their first priority in 1963 was to secure independence. ${ }^{46}$

In September 1964 Douglas-Home said he would accept the 1961 Constitution as a formula for independence if Smith could prove that the majority of the inhabitants of Rhodesia were in favour [sic] of it. Smith's response was to hold a referendum on the issue and to convene an indaba of tribal chiefs and headmen, arguing that, as eight of ten Africans lived in the tribal areas and as the membership of the African nationalist parties had been concentrated in the towns, the chiefs reflected tribal opinion. Both produced results favourable [sic] to Smith but were rejected by the new Labour Government of Harold Wilson . . . . ${ }^{7}$

In April 1964, amidst rising pressure, the Prime Minister resigned and Ian Smith became Rhodesia's first native-born Prime Minister. ${ }^{48}$ Smith's advent

39. Rhodesian Insurgency, supra note 18.

40. Id.

41. Id.

42. Id.

43. Id.

44. See id.

45. Rhodesian Insurgency, supra note 18.

46. Id.

47. Id. "A British general election was due in 1964 and Macmillan's replacement as prime minister, Sir Alex Douglas-Home, was reluctant to take a decision which might break the Commonwealth." Id.

48. BOYNTON, supra note 28 , at 65. 
to power was followed by the detention of Nkomo, which led to riots in the African townships. ${ }^{49}$

On November 11, 1965, Ian Smith went on the radio and unilaterally declared independence (UDI). ${ }^{50}$ "Britain recoiled in angers at this first rebellion by a British territory since the American Revolution. . . . Wilson applied sanctions and backed them by deploying two carrier task forces to cut off Rhodesia's supply of oil."51 Later, to secure international co-operation, Wilson engineered mandatory sanctions from the United Nations under Chapter VII of the Charter. ${ }^{52}$ Selective sanctions were imposed against the regime in 1966 and these were made total in 1968. Sanctions busting became a national priority and was refined to an art. ${ }^{53}$ Sanctions were also weakened by the co-operation of Rhodesia's neighbors, Portuguese-ruled Mozambique and South Africa. ${ }^{54}$

\section{Second ChImurenga: Phase I}

Rhodesian Intelligence broke down the Rhodesian Conflict into three phases. ${ }^{55}$ Phase One was from UDI until $1968 .{ }^{56}$ Phase Two saw a complete cessation of insurgent movements. ${ }^{57}$ Phase Three, from 1972 until 1980 saw the collapse of Portuguese rule in neighboring Mozambique, and the intensification of insurgent movements within Rhodesia. ${ }^{58}$ This phase allegedly saw the use of bacteriological and chemical weapons. ${ }^{59}$

49. Rhodesian Insurgency, supra note 18.

50. See SMTrH, supra note 30, at 103-06.

51. Rhodesian Insurgency, supra note 18.

52. Id.

53. See generally NESBIT \& COWDEROY, supra note 7, at 56-65. An entire wing of the Rhodesian Air Force was dedicated to sanctions busting. See id. at 57. Some of the clandestine tactics utilized included: flying planes with fake tail numbers; falsifying bills of lading with false country receivers; forming 'dummy' corporations in third countries. See id. at 57 . For example, the Rhodesian Air Force flew Alouette helicopters for missions against the insurgents. The French producer of the Alouette complied with the UN arms embargo. The Rhodesians merely set-up a dummy civilian corporation in a neighboring African country which had an Alouette. In the life of this 'company,' the single Alouette required numerous engine repairs, dozens of gear boxes and tail rotor replacements. See id. at 56-58.

54. See Rhodesian Insurgency, supra note 18.

55. See NESBIT \& COWDEROY, supra note 7, at 29.

56. See id.

57. See id.

58. See id. at 39.

59. See id. at 41-43. This period saw an increase in military tactics, including the use of Fireforce operations, in which air support was coupled with ground troops. See id. at 40 . One Fireforce volunteer described one of these Fireforce operations as using aircraft carrying “"SNEB rockets [ $68 \mathrm{~mm}$ diameter, usually of French origin] and Frantan [napalm bombs]." See id. at 42 (quoting an anonymous helicopter pilot who flew during these Fireforce operations). The security forces were also said to have poisoned or doctored food and water supplies to gain tactical advantage over the guerilla forces. See id. at 46. 
Phase One was characterized by small-scale incursions into Rhodesia, mainly from newly independent Zambia. ${ }^{60}$ The incursions were a "complete failure." ${ }^{\prime 61}$ On April 28, 1966, the first 'battle' occurred when seven rebel soldiers infiltrated Rhodesia in an attempt to occupy the town of Sinoia. ${ }^{62}$ In quick order, the BSAP (Rhodesian police) dispatched the infiltrators. ${ }^{63}$ Nonetheless, the April 28 battle is the date by which blacks commemorate the second uprising against the white colonizers, which they call the beginning of the Second Chimurenga ${ }^{64}$ From April 1966 onwards, groups of guerrillas infiltrated Rhodesia from neighboring Zambia in steadily increasing numbers, but the war remained a relatively minor police action. ${ }^{65}$

\section{A. Phase III and the Use of Biological Weapons}

After their collapse in 1966, the guerilla movements took different approaches to overthrowing the Smith regime. ZIPRA, led by Nkomo ${ }^{66}$ and influenced by the U.S.S.R., concentrated on invading Rhodesia as a conventional army. ${ }^{67}$ ZANLA, led by Robert Mugabe, and influenced by China, adopted a Maoist strategy of winning the hearts and minds of the rural population and waging a guerilla war in the eastern border areas of Rhodesia. ${ }^{68}$ Phase Three was the most intense and it began on December 21, 1972, when ZANLA attacked a farm in the Centenary District, with further attacks on other farms in the following days. ${ }^{69}$ As the guerrilla activity increased in 1973, "Operation Hurricane" ${ }^{70}$ began, and the military prepared itself for all out

60. NESBIT \& COWDEROY, supra note 7, at 29.

61. BRUCE HOFFMAN ET AL., LESSONS FOR CONTEMPORARY COUNTERINSURGENCY: THE RHODESIAN EXPERIENCE 7 (1991).

62. See NESBIT \& COWDEROY, supra note 7, at 20-31.

63. See id.

64. See id. at 33. April 28th is celebrated as 'Chimurenga Day.' Id. at 33.

65. See id. at 35.

66. See BoynTon, supra note 28 , at 75.

67. See HOFFMAN ET AL., supra note 61, at 9. "ZIPRA did not altogether abandon guerilla warfare, and until 1972, its insurgents conducted hit-and-run raids across the Zambezi River to mine roads in the game reserves frequented by tourists." See id. at 9, n.3.

68. See id. at 9. The Land Apportionment Act of 1930 divided Rhodesia into distinct farming communities-excluding black Africans from ownership of the best farmland. See Background to the Land Question in Zimbabwe, at http://www.mathaba.net/africa/ zimlandhistory.htm (last visited Feb. 17, 2003). Whites were given the most fertile land. See id. Whites received around fifty-one percent of the land and blacks received around twenty-two percent of the land, while the rest was set aside for future purchasing. See id. This resentment may have contributed to recruitment drives by the guerillas.

69. See J.K. CILLIERS, COUNTER-INSURGENCY IN RHODESIA 13 (1985); see also BOYNTON, supra note 28 , at 75.

70. See CILLIERS, supra note 69, at 14-15. Operation Hurricane was the code-name of a "Joint Operation Centre [sic] . . formed at Army Brigade level of command to counter the internal threat that had developed." Id. at 15. Operation Hurricane represented a "committee system approach" to combating insurgent forces in the country, whereby Army, Air Force, and British South African Police collaborated to stem "the flow of insurgents" and to control the 
war. $^{71}$ During 1974 , a major effort by the security forces resulted in many guerrillas being killed and the number inside the country was reduced to "between three and four hundred." 72

In 1974, a coup in Lisbon ushered in the end of the Portuguese empire in Africa. ${ }^{73}$ Almost immediately after the coup, Portuguese colonial troops stopped their patrols and remained in their bases. ${ }^{74}$ Even though Portugal was still nominally in control, the effect was to create a second open front along Rhodesia's long border with Mozambique, which was exploited by ZANLA. ${ }^{75}$ In 1975, the Portuguese left Mozambique, and a Marxist government, sympathetic to the Zimbabwean nationalist cause, came to power in the former colony, which aided the guerillas in their attacks along the MozambiqueRhodesian border. ${ }^{76}$

As the guerilla war heated up, the BSAP was soon overwhelmed and the government turned to the security forces. The Rhodesians had inherited a number of military units from the Federation break-up. ${ }^{77}$ Most important were: 1) the Rhodesian Air Force (RhAF); 2) the Army; consisting of: a) the SAS $;{ }^{78}$ b) the Rhodesian African Rifles (formerly a unit of the King's African Rifles, and an anachronism of the Victorian era, in which white officers commanded blacks) $;{ }^{79}$ c) the Rhodesian Light Infantry (RLI); ${ }^{80}$ and d) the Armoured Car Regiment, collectively, the "Security Forces." Rhodesians made a strategic decision and made special operations (mainly the SAS, RLI, and RhAF) their primary function and traditional military units their secondary option (i.e. the Armored Car Regiment). ${ }^{82}$ They took the

population within the country. $I d$.

71. See generally id.

72. See id. at 21.

73. See id. at 19.

74. See CILLIERS, supra note 69 , at 19-20.

75. See BEST \& BLIJ, supra note 14, at 306-08. See also CILLIERS, supra note 69, at 19.

76. See BEST \& BLIJ, supra note 14 , at 306.

77. See generally ABBOTT \& BOTHAM, supra note 5, at 15-39 (describing and giving the history of the Rhodesian Security Forces inherited by the government after UDI).

78. See id. at 18. Originally a part of the British SAS, the Rhodesian contingent was founded in 1950. See id. The unit trained as late as 1962 with the British SAS in Aden. See id. This unit was the elite of the Rhodesian military.

79. See ABBOTT \& BOTHAM, supra note 5, at 14-15. The RAR was the oldest unit in the Army, founded in 1940. See id. at 14. Black officers were finally allowed in 1979. See id.; see generally MALCOM PAGE, KAR: A HISTORY OF THE KING'S AFRICAN RIFLES \& EAST AFRICAN FORCES (1998) (providing a general history of the King's African Rifles, including the RAR).

80. See ABвоTT \& BotHAM, supra note 5, at 17. The RLI was formed in 1961 as the Federation's European Army. See id. The RLI, similar to the SAS, was never integrated. See id.; see generally CHRIS COCKS, FIREFORCE: ONE MAN'S WAR IN THE RHODESIAN LIGHT INFANTRY (1988) (giving a general history of the RLI).

81. See ABBOTT \& BothAM, supra note 5, at 21. The Armored Car Regiment was formed in 1941, it was disbanded upon break-up of the federation, but was resurrected in 1972. See id.

82. See HOFFMAN ET AL., supra note 61, at 23-24 (the Rhodesians showed the world that small bands of guerillas are best fought by small highly trained bands of special operation units in the field). 
lessons learned by their SAS in Malaysia, from the British in Kenya against the Mau Mau, and the United States experience in Vietnam and adopted it to their war. Although they mastered the art of counter insurgency operationsusing the SAS - and the mobile use of helicopter borne troops, the Rhodesians -because of their racist policies-were never able to win the campaign for the 'hearts and minds' of black Africans, a prerequisite in any guerilla campaign. ${ }^{83}$

In the early 1970s, the Rhodesians turned to a concept called 'pseudo operations ${ }^{84}$ (pseudo ops), creating the Selous Scouts in 1973 and placing the unit under the auspices of the Central Intelligence Organization's (hereinafter "CIO") Special Branch, rather than the Army ${ }^{85}$ Security personnel would dress as insurgents and infiltrate rural communities seeking out real insurgents. ${ }^{86}$ When they found the real insurgents, they could opt for an engagement or call in their position and allow other army units, notably the RLI, to come in. At first, highly trained white officers of the SAS were used for the operations. But language barriers and the distinct physical facial features of the whites necessitated the use of black Zimbabweans. To do so, injured or captured insurgents were "turned" and made to serve the Selous Scouts. ${ }^{87}$ Thus compromised, they could never return to their villages and were beholden to the regime for the remainder of their lives. ${ }^{88}$ The new recruits were able to provide intelligence and the latest call signs used by the real insurgents. The British had used a similar pseudo ops concept in Malaya and Kenya. ${ }^{89}$ The Selous Scouts were housed in a secret facility near Mount Darwin within the Hurricane Theatre of the war. "The Selous Scouts proved extremely effective in providing the security forces with useful and timely intelligence ... [and] were responsible for a staggering 68 percent of all insurgent kills and captures in their areas of operation." 90

The CIO consisted of two branches, Special Branch responsible for internal security -thus the placement of the Scouts under its wings-and Branch II, which was responsible for external operations, propaganda, disinformation, covert ops, and psychological operations. ${ }^{91}$ The Selous Scouts' unrivalled tracking abilities, survival and counter insurgency skills made them one of the most feared and hated of the army units. ${ }^{92}$ The unit was known for

83. See id. at 26-27.

84. See id. at 31. "Pseudo-or 'counter-gang' operations were initiated." See id.

85. See Ron R. Daly, LT. Col. (ret.), SElous SCOUTS: TOP SECRET WAR (1983). For a general history of this unit see HOFFMAN ET AL., supra note 61, at 31; see also NESBIT \& COWDEROY, supra note 7, at 39.

86. See HOFFMAN ET AL., supra note 61, at 32.

87. See id.

88. See Jeremy Brickhill, Zimbabwe's Poisoned Legacy: Secret War in Southern Africa, COVERT ACTION, No. 43, 6 (Winter 1992/93).

89. See HOFFMAN ET AL., supra note 61 , at 32.

90. Id. at 33.

91. See id. at 28 (citing CILLIERS, supra note 69, at 218-19).

92. See, e.g., Brickhill, supra note 88 , at 6 . 
"murder, rape, smuggling, and poaching," $" 93$ and its members were "psychopathic killers" 94 and "vainglorious extroverts." "To avoid confusion and prevent other government forces from mistaking the Scouts for actual insurgents, any area they were operating in was 'frozen'-that is no other security forces were allowed in its vicinity." 96

In 1976, Operations "Thrasher" and "Repulse" started in order to contain the ever-increasing influx of guerrillas. ${ }^{97}$ At the same time, rivalry between the two main guerrilla factions increased and resulted in open fighting in the training camps in Tanzania, with over 600 deaths. ${ }^{98}$ The Soviets increased their influence and began to take a more active role in the training and control of the ZIPRA guerrillas. ${ }^{99}$ New tactics were developed on both sides. The Rhodesians decided to take the war to the enemy. Cross-border operations-which had started in 1976 with a raid on a major base in Mozambique in which the Rhodesians had killed over 1,200 guerrillas and captured huge amounts of weapons-were stepped up by the SAS and later the Selous Scouts. ${ }^{100}$ Attacks on large guerrilla camps such as Chimoio and Tembue resulted in thousands of guerrilla deaths and the capture of supplies sorely needed by the Rhodesians. ${ }^{101}$ The concept of "Fireforce" 102 was also introduced at this time. The Fireforce concept involved helicopters inserting a "stick" of men from the RLI into an area identified by Selous Scouts as containing insurgents. ${ }^{103}$ The war externally and internally was "heating-up" for the Rhodesians. By 1976, "no one would say so in public-except for the very public act of emigrating - but in private many were prepared to admit that even if defeat was unlikely, victory was impossible."104 From 1976-78 the war was at its most intense-during this period it is alleged that biological and chemical weapons were used.

93. Id. at 7.

94. Id.

95. Id.

96. HOFPMAN ET AL., supra note 61, at 33; see also ClLLIERS, supra note 69, at 102, $\mathrm{n}$. 4 (citing Rhodesian Army Manual Military Support to the Civil Order, 1976, at xvi, defining a no go area as: "one from which all civilians are excluded by an order of the Protecting Authority .... Only authorised members of the Security Forces, on duty, will move in no-go areas and no action may be instituted against them for any death or injury caused to any person within the area.").

97. See CILLIERS, supra note 69, at 239. In 1973/74 there were a few 'hundred' insurgents within Rhodesia. See id. By 1977, CIO estimated that the combined ZANU/ZIPRA force numbered over '5000.' See id. By 1978, the figure was over 9000 . See id.

98. See Rhodesian Insurgency, supra note 18.

99. HUFFMAN ET AL., supra note 61, at 34.

100. See generally id. at 77-87.

101. See id. at 80.

102. See id. at 21. "Fireforce" was the combination of Rhodesian Airforce and Army units, which used helicopters in raids. For more information see generally NESBIT \& COWDEROY, supra note 7, at 34-46.

103. See NESBIT \& COWDEROY, supra note 7, at 40.

104. See PETER GodwIN \& IAN HaNCOCK, RHOdesians NeVER Die 171(1993). 


\section{B. The End of the War}

By March 1978, Smith-ready to end the war-hammered out an internal settlement. ${ }^{105}$ A black Prime Minister was elected through universal suffrage, but the military and intelligence apparatus remained in firm white control. ${ }^{106}$ The international community refused to recognize ZimbabweRhodesia as it was known. ${ }^{107}$ In June 1978, the war spiraled out of control, as insurgents shot a civilian airliner out of the sky. ${ }^{108}$ Some passengers managed to survive, only to be butchered on the ground by the insurgents. In retaliation, in October 1978 Rhodesian forces invaded Zambia and Mozambique, killing thousands of guerillas in training camps. ${ }^{109}$ Britain and the United States condemned the raids, saying they could lead to a superpower confrontation in Southern Africa.

Towards the end of 1979, talks had begun at Lancaster House in England, with both sides seriously interested in stopping the war, but Rhodesian cross-border raids continued; hitting supply-lines, strategic bridges, and railways in an effort to convince Zambia and Mozambique to put pressure on the guerrilla leaders to end the war. ${ }^{110}$ Rhodesian losses in men and aircraft were increasing, whereas the supply of equipment and recruits to the guerrillas seemed endless. By the end of 1979, therefore, it was becoming obvious that the Rhodesians would be unable to end the war, despite that their troops were winning every battle and skirmish they engaged in. With the war unwinnable and white emigration on the rise, Ian Smith signed the Lancaster House Agreement in December of 1979. ${ }^{11}$ The Agreement ushered in majority rule fourteen years after Smith's UDI. ${ }^{12}$ In effect, the clock was turned back to 1965, and a British Governor arrived on December 12, 1979. All parties

105. See SMITH, supra note 30, at 249.

106. See ABBOTT \& BOTHAM, supra note 5, at 7. The South Africans took "an active role, out of self interest in behind-the-scenes diplomatic moves with Zambia, Tanzania, and Botswana to help create an atmosphere in which constitutional settlement might be achieved." See BEST \& BLIJ, supra note 14, at 307.

107. See АВBOTT \& BOTHAM, supra note 5, at 6.

108. GODWIN \& HANCOCK, supra note 104 , at 228 . The airplane was hit by a SAM 7 missile. See id. The pilot was able to land the plane safely, but at the last moment, hit a ditch and the plane broke in two. See id. Eighteen people survived the crash. See id. Five of the least injured went to get help. See id. Soon afterward, insurgents showed up and killed ten of the thirteen still alive. See id. ZIPRA's head, Nkomo, claimed responsibility, and a rumor that he laughed about killing civilians sent Rhodesia over the edge. See id.

109. See GODWIN \& HANCOCK, supra note 104, at 232. The operation in Zambia led to the RhAF being in control of Zambian airspace for over thirty minutes. See id. at 233. The action boosted morale in Rhodesia as the tape was played on the television. See id. at 234.

110. See HOFFMAN ET AL., supra note 61, at $82-90$ for an exhaustive list of these crossborder raids into neighboring countries.

111. See ABBOTT \& BOTHAM, supra note 5, at 7; see also NESBIT \& COWDEROY, supra note 7 , at 110 .

112. See SMITH, supra note 30, at 329. 
signed a ceasefire agreement on December 21,1979 . The Union Jack was raised upon his arrival, only to be lowered on April 9, 1980, as the nation of Zimbabwe emerged to join the family of nations. ${ }^{113}$

\section{The DiRTY TRICKS: BIOLOGICAL AND CHEMICAL WEAPONS}

Early in 1976, the security forces, farmers, and officials urged the government to impose firmer and swifter methods of justice on the "terrorist." From 1976 onward, the "gloves were off" against the insurgents. ${ }^{114}$ The Army's Psychological Operations Unit (PSYOPS) presented a plan to eliminate terrorists. The aim of PSYOPS was: "to kill and capture terrorists and to win over the local population." 15 The RLI began to kill prisoners it captured in the field. ${ }^{116}$ Government assassination of opposition members was authorized and ZANU's national chairman was assassinated in Zambia by CIO operatives. ${ }^{17}$ Zambian officials sympathetic to ZANU rounded up other leaders because of disinformation implicating them in the assassination. The loss of the leadership set ZANU back politically at least two years, according to the $\mathrm{CIO} .{ }^{118}$

The effectiveness of the assassination and the desperation of the war effort, lead to the use of bacteriological and chemical weapons as "dirty tricks." In the late 1970s, under siege, the orders were given to use chemical and biological agents against the enemy. ${ }^{119}$ The techniques used were: a) poisoning wells; b) spreading cholera; c) infecting clothing used by "terrorists;" and d) using anthrax to kill cattle, thus denying food supplies to the guerillas. ${ }^{120}$

Doctors and chemists from the University of Rhodesia were recruited by the CIO in 1975 and asked to identify chemical and biological agents that could be used against the guerillas. ${ }^{121}$ Professor Robert Symington is credited as being the father of Rhodesia's biological warfare program. ${ }^{122}$ Symington developed Rhodesia's stockpile of toxins and other agents to help 'supplement' the war effort by the Rhodesian forces. ${ }^{123}$ The Rhodesians used

113. See PACKENHAM, supra note 1 , at 671.

114. CILLERS, supra note 69 , at 168.

115. Id. at 154.

116. See CoCKS, supra note 80 , at 236.

117. See GODWIN \& HANCOCK, supra note 104, at 117; see also HOFMAN ET AL., supra note 61 , at 35 .

118. See HOFFMAN ET AL., supra note 61 , at 35.

119. See Tom Mangold \& JefF Goldberg, Plague Wars: a True Story of BIOLOGICAL WARFARE 216 (1999).

120. See id. at 222.

121. See id.

122. See id. at 226.

123. See id. at 142. 
three toxins: a) Ricin, ${ }^{124}$ an extremely potent toxin that "comes from the castor bean and enters the body intravenously" ${ }^{23}$; b) Thallium, a lethal heavy metal similar to rat poison; and c) Parathion. ${ }^{126}$ By 1975 , clinical trials were performed on humans-a clear and recognized crime against humanity-provided by the CIO from the Selous Scouts' secret detention center in Mount Darwin. ${ }^{127}$ The doctors would administer various agents to the prisoners, experimenting with agents and dosages. ${ }^{128}$ The CIO then disposed of the bodies of the victims down mine shafts. ${ }^{129}$

By 1976, deployments of the agents were ready and carried out by the CIO, Selous Scouts, and South Africans. ${ }^{130}$ The chemical and biological agents used by the CIO in the field included: thallium, organophosphates poisons, warfarin, "anthrax bacterium," and other as yet unidentified bacteriological agents. ${ }^{131}$ The CIO and the Scouts used thallium at first. Thallium was injected into canned meat and through the use of pseudo ops techniques, the poisoned meat was given to insurgents who believed they were being re-supplied by other friendly insurgents. ${ }^{132}$ In one instance, because of a shortage of food in the Tribal Trust Lands-another deliberate tactic of the CIO and PSYOPS-the guerillas gave their thallium-laced food to innocent villagers, thus killing them. ${ }^{133}$

Unfortunately for the $\mathrm{CIO}$, the use of thallium became known. Neither the manufacturer of the canned meat, nor the Ministry of Health knew of this program. ${ }^{134}$ They began an investigation that ultimately led to the uncovering of the facts in the case. ${ }^{135}$ In another incident, holes were drilled into bottles of liquor and laced with cyanide or poisons. ${ }^{136}$ In their unwavering use of pseudo ops, Selous Scouts-perhaps in an attempt to show that the guerillas

124. See FrEdRICK R. SIDELL ET AL., JANE'S: CHEM-BIO HANDBOOK 142 (1999). "Ricin is a toxin made from the mash that is left over after processing castor beans." Id. Since processing is worldwide, the material is "easily available." See id.

125. MANGOLD \& GOLDBERG, supra note 119 , at 226.

126. See id.

127. See id. at 222-23.

128. See id.

129. See id. at 223.

130. See id. "South African military and security personnel who not only acted as advisers and monitors, but likely played some part in the development of the chemical and biological agents." See MANGOLD \& GOLDBERG, supra note 119, at 221-23.

131. See id.

132. See id. at 223.

133. See HENRIK ELLERT, THE RHODESIAN FRONT WAR: COUNTER-INSURGENCY AND GUERILLA WAR IN RHODESIA 1962-1980 146-47 (1989). Ellert was a former head in the CIO Special Branch section, which makes his allegations that much more credible. See id. at vi. See also Al Venter, Biological Warfare: The Poor Man's Atomic Bomb, JANE's INTELlugEnCE R., Vol. 11, No. 3, Mar. 1, 1999, at 43.

134. See MANGOLD \& GOLDBERG, supra note 119, at 223 (citing ELLERT, supra note 133, at $146-47)$.

135. See id.

136. See Venter, supra note 133, at 43. 
were responsible - used an unknown poison to contaminate a well near heavy guerilla activity close to the Mozambique border. ${ }^{137}$ At least 200 civilians died because the well was the sole source of drinking water for the area. ${ }^{138}$ Selous Scouts were instructed to poison watering holes, stagnant water, slow moving streams, and other bodies of water ${ }^{139}$ near guerilla camps inside the Mozambiquean border, as such sources were essential for supply lines. ${ }^{140}$

Cholera was also alleged to have been used by the CIO. ${ }^{141}$ Selous Scouts were told to spread the disease near the border. SAS operativesresponsible for external raids-probably spread cholera inside Mozambique. Nevertheless, the ClO was worried that the use of cholera could backfire and spread into Zimbabwe uncontrolled and affect the Selous Scouts who operated in the field. ${ }^{142}$ Selous Scouts were also told to dump cholera in water supplies, most notably the Ruya River. This incident corresponds to a cholera epidemic along the Mozambican side of the river in which an unknown number of fatalities occurred. ${ }^{143}$ This practice was discontinued because the agent was thought to dissipate too quickly to provide any lasting tactical advantage.

The Rhodesians, with possible assistance from the South Africans launched a program of contaminating clothing. In a mea culpa account, Ken Flower, the Chief of the CIO stated:

For more years than I would like to tell, young men were recruited for the guerilla cause under the aegis of CIO and with the willing co-operation of Kanodareka and his helpers who supplied them with poisoned uniforms. The men would be sent on their way to the guerilla training camps, but before reaching, their destination would die a slow death in the African bush. Many hundreds of recruits became victims of this operation. It became so diabolically successful that exposure seemed inevitable and so the principal perpetrators had to be eliminated [Kanodareka] -rather as a hunter will finish off a wounded animal to stop further suffering. ${ }^{144}$

137. See id.

138. See MANGOLD \& GOLDBERG, supra note 119 , at 223 ; see also GoDWIN \& HANCOCK, supra note 104, at 8 (citing ELLERT, supra note 133, at 112).

139. See SIDELLET AL., supra note 124, at 129-30. Cholera exposure is through contact with contaminated water. See id. It can "thrive in saline water or water polluted with organic matter for up to six weeks." Id.

140. See MANGOLD \& GOLDBERG, supra note 119, at 222. 18.

141. See Smith's Chemical Warfare Secrets Revealed, THE OBSERVER, Nov. 10, 1991, at

142. See MANGOLD \& GOLDBERG, supra note 119, at 222.

143. See GODWIN \& HANCOCK, supra note 104, at 8.

144. KEN FLOWER, SER VING SECRETLY: AN INTELLIGENCE CHIEF ON RECORD RHODESIA INTO ZIMBABWE 1964 TO 1981137 (1987). 
The South Africans had two dedicated biological weapons facilities, the Institute of Virology in Johannesburg and the other in a South African Defense Force, (hereinafter, "SADF") veterinary facility near Pretoria. ${ }^{145}$ Under an umbrella project named "Alcora,"146 the South Africans and Rhodesians used poisoning agents. ${ }^{147}$ According to a former ClO Officer, they:

[W]ould give us briefings about certain places and we would be warned that the drinking water or, you know, the wells might have been poisoned - but our soldiers didn't do it. There were places where we were categorically told that the waters had been salted [sic] with cholera and we would have to be careful. Truth is, Rhodesia was being used as a laboratory. There were civilian operators, strange types from South Africa .... To be more precise it was South African military intelligence. ${ }^{148}$

Sweatshirts, uniforms, and other apparel were soaked in chemicals ${ }^{149}$ and through the Selous Scouts, these were distributed to insurgent groups near the border with Mozambique. The Rhodesians used organophosphates to poison the clothing of guerillas. ${ }^{150}$

\section{A. Anthrax in Rhodesia}

For centuries, bacillus anthracis, anthrax, has caused disease in animals and uncommonly, serious illness in humans throughout the world. ${ }^{151}$ Anthrax is endemic to certain parts of Africa. ${ }^{152}$ Naturally occurring anthrax is a disease acquired following contact with an anthrax infested animal or its

145. Questions About the Involvement of South Africa Apartheid Regime and its Secret Services in External Operations Like Hit Squads, Chemical and Biological Warfare, (Nov. 1997), at http://www.contrast .org/truth/html/chemical__biological_weapons.html (last visited Feb. 21, 2003) [hereinafter Chemical \& Biological Warfare].

146. See id.

147. See id. The Portuguese were also involved in the project before their empire collapsed. See id.

148. MANGOLD \& GOLDBERG, supra note 119, at 221-22.

149. See Chemical \& Biological Warfare, supra note 145.

150. See Smith's Chemical Warfare Secrets Revealed, supra note 141. After independence, Professor Symington moved to South Africa, and is alleged to have participated in making biological and chemical weapons in that country. See GoDWIN \& HANCOCK, supra note 104 , at 8 .

151. See Anthraxas a Biological Weapon, JAMA, Vol. 281, No. 18 [hereinafter Biological Weapon].

152. See Melissa Hendricks, Germ War: Designing Disease, WASH. POST, Jan. 1, 1989, LEXIS; see also, Erica Weir, Anthrax: Of Bison and Terrorism, CAN. MED. ASS'N J., Sept. 5 , 2000, LEXIS. 
byproducts. ${ }^{153}$ Herbivores are the most common carrier, they usually ingest anthrax spoors residing in the soil. ${ }^{154}$ Animal vaccination programs have reduced the rate of infection among animals. ${ }^{155}$ In humans, the disease is not contagious, thus it cannot be spread readily from one human to another. Three types of human anthrax infection can occur: 1) inhalational, where spores enter the lungs and within a month or some times less, release two types of toxins which result in blood poisoning; 2) cutaneous or subcutaneous, in which the bacteria penetrates the skin; and 3) gastrointestinal, in which the spores are ingested. ${ }^{156}$ Cutaneous Anthrax is the most common natural form of the disease with an estimated 2000 cases reported annually. ${ }^{157}$ The human disease typically follows exposure to a diseased animal. ${ }^{158}$ Research into the use of anthrax as a weapon began more than eighty years ago, and it remains a popular choice as a weapon of terror, particularly in it its most deadly inhalation form. ${ }^{159}$

In Rhodesia before 1978, there was an average of thirteen cases of anthrax a year. ${ }^{160}$ By 1979, the Department of Veterinary Services announced that a cattle-borne illness of anthrax had broken out in three Tribal Trust Lands. ${ }^{161}$ The disease claimed twenty-one people. ${ }^{162}$ But, there was an inconsistency. On October 19 , three days after its announcement, the government announced that the anthrax outbreak had spread to six Tribal Trust Lands. ${ }^{163}$ From 1978-80, 10,783 Zimbabweans were infected and 182-all black Zimbabweans-died of cutaneous anthrax. ${ }^{164}$ A confidential former Rhodesian officer recently reported,

It is true that anthrax spoor was used in an experimental role in the Gutu, Chilimanzi, Masvingo, and Mberengwa areas, and the anthrax idea came from army Psyops .... The use of anthrax spoor to kill off the cattle of tribesmen . . . was carried out in conjunction with [the] psychological suggestion to the tribes people that their cattle were sick and dying

153. See Biological Weapon, supra note 151, at 1736.

154. See id.

155. See id.

156. See SIDELLET AL., supra note 124, at 126-28.

157. See Biological Weapon, supra note 151, at 1736; see also First Response to Terror, INSIGHT ON THE NEWS, Jan. 26, 1998, at 10.

158. See Biological Weapon, supra note 151, at 1736.

159. See id.

160. See MANGOLD \& GOLDBERG, supra note 119, at 218.

161. See Zimbabwe-Rhodesia: In Brief; Anthrax Outbreak in Matabeleland TTLs, BBC (London), Oct. 16, 1979.

162. See id.

163. See Zimbabwe Rhodesia: In Brief: Outbreak of Anthrax, BBC (London), Oct. 19, 1979.

164. See Rhodesia Forces Used Anthrax, Cholera in Guerilla Warfare, AGENCE FRANCE PRESSE (Paris) July 8, 1993 [hereinafter Rhodesia Forces]. 
because of disease introduced into Zimbabwe from Mozambique by the infiltrating guerillas. ${ }^{165}$

According to another report, a former member of the Rhodesian forces, anthrax was used to kill the cattle of the Zimbabweans. ${ }^{166}$ The operation was to reinforce the notion that foreign guerillas were bringing back diseases that would kill cattle. This was another variation of PSYOPS, in its ongoing campaign to alienate the local population from the insurgents. ${ }^{167}$ In contrast to the devastation in the black Tribal Trust Lands, only eleven cases of human infections were reported-with no deaths-in the European farming areas. ${ }^{168}$

The use of anthrax as a weapon of last resort is not far fetched. The area of northeastern Zimbabwe has ideal conditions, with the right mixture of alkaline $\mathrm{pH}$, nitrogen, calcium, and organic matter. ${ }^{169}$ In attempting to crush their opponents and maintain their white minority regime, the Rhodesians, according to Cilliers, often used food as a weapon. ${ }^{170}$ On January 28,1977 , the Rhodesian government introduced an amendment to the Emergency Powers whereby control of food supplies was instituted in various areas of Rhodesia. ${ }^{171}$ PSYOPS pushed for food control to keep ZANLA insurgents from obtaining food from friendly rural blacks that worked on the white farms. ${ }^{172}$ PSYOPS instituted Operation Turkey in 1977. ${ }^{173}$ The aim of Operation Turkey was twofold: a) cut the food supply to ZANLA; and b) increase animosity between the insurgents and the local population by controlling the supply of food. ${ }^{174}$ The Operation was relatively successfulguerillas, believing that they were poisoned by villagers sought out and destroyed villages and killed villagers who had prepared food for them. Further restrictions were put upon the blacks by PSYOPS, such as introducing ration cards, placing limits on the amount of food available in stores, and limits on bulk purchases. ${ }^{175}$ Viewed from this perspective, anthrax may have been a strong part of a plan to reduce food stocks to the native population and not-like the chemical and cholera incidents-an effort at direct genocide.

165. MANGOLD \& GOLDBERG, supra note 119, at 222.

166. See Rhodesia Forces, supra note 164.

167. See Cilliers, supra note 69 , at 40.

168. See Rhodesia Forces, supra note 164; see also Meryl Nass, Anthrax Epitzootic in Zimbabwe, 1978-80: Due to Deliberate Spread?, PSR QUARTERLY, Vol. 2, No. 4, 198, Dec. 1992, at http://www.anthraxvaccine.org/zimbabwe.html (last visited Mar. 4, 2003).

169. See MANGOLD \& GOLDBERG, supra note 119, at 217.

170. See generally CILLIERS, supra note 69, at 158-60.

171. See id. at 158.

172. See id.

173. See id. at 159.

174. See id.

175. See id.; see also GodWIN \& HANCOCK, supra note 104, at 6. 


\section{B. The Nass Report}

The first non-Zimbabwean to suspect the deliberate use of anthrax was an American doctor, Meryl Nass, a biological warfare epidemiologist. ${ }^{176}$ From 1989-92, she researched the events of 1978-80. ${ }^{177}$ She became interested in how anthrax spores spread so quickly-even in the absence of bovine cases-and engulfed six of the eight Rhodesian provinces. ${ }^{178}$ Even more remarkable was that the white farmers lost only four heads of cattle, with eleven cases of human exposure and no deaths. ${ }^{179}$ Nonetheless, why does Nass believe that it was a deliberate spread? First, the large amounts of those infected. Rhodesia had had only 334 cases from 1950-1978. ${ }^{180}$ Doctors in Zimbabwe in 1977 had rarely seen an anthrax case. Yet, during the war, anthrax became one of the country's major causes of hospital admissions. ${ }^{181}$ Next, the large-scale infestation is additional proof of a deliberate spread. Most anthrax outbreaks have a high degree of focality. ${ }^{182}$ In Zimbabwe most of the Tribal Trust Lands stretching across six of the eight Provinces were infected. ${ }^{183}$ Many of the cases occurred in areas where there had not been a previous case. The outbreak was centered only in Zimbabwe. ${ }^{184}$ None of its neighbors, according to Nass, had higher than normal reporting of infections. ${ }^{185}$ Finally, Nass points out that the outbreak occurred when the war intensified to its greatest levels. ${ }^{186}$ Nass, however ends her investigation into the use of anthrax, by concluding that " $[\mathrm{t}]$ here exists no generally accepted methodology to serve as a guide for the design of an investigation into the possible use of biological weapons."187

\section{Analysis of Anthrax and Other Bacteriological Agents}

Drawing inferences from the circumstantial evidence particularly when coupled with the personal accounts—of which Flower's and Ellert's personal mea culpas are the most convincing-leads one to the conclusion that biological weapons were used in Rhodesia by the security forces. Notwithstanding, Ian Smith's flippant response when confronted by a reporter

176. See MANGOLD \& GOLDBERG, supra note 119, at 218.

177. See id.

178. See id.

179. See Nass, supra note 168; see also Rhodesia Forces, supra note 164; see also MANGOLD \& GOLDBERG, supra note 119 , at 218.

180. See Nass, supra note 168.

181. See id.

182. See id.

183. See id.

184. See id.

185. See id.

186. See Nass, supra note 168.

187. Id. 
over the alleged use of these weapons was, "first time I've ever heard about it." 188 While there is one explanation for a possible natural occurrence it is not convincing under the circumstances: by mid-1978 veterinary services outside the white farming area had collapsed and the services were no longer provided. ${ }^{189}$ Because of the level of violence in the countryside, inoculation of cattle against diseases had become sporadic since at least 1974 and even then, vets were sent in with armed soldiers. ${ }^{190}$ Malaria, bilharzias, and other endemic diseases soared during the period of the anthrax spread. ${ }^{191}$ Yet, the collapse of the veterinary and medical system alone does not provide a satisfactory explanation of a naturally occurring outbreak of anthrax. The reason is that anthrax vaccination was not practiced in Zimbabwe even before the outbreak because of the low prevalence of the disease. ${ }^{192}$ As a consequence, the collapse of veterinary services would not have had a major impact on cattle in the Tribal Trust Lands. ${ }^{193}$ The collapse did affect other diseases, such as preventable tick-borne diseases. ${ }^{194}$ Between 1975-79 an estimated 250,000 head of cattle died because "dipping" services in the rural areas had been shut down. ${ }^{195}$ Sleeping sickness also rose dramatically during this period. ${ }^{196}$

Additional inferences of a deliberate spread can be gleaned from other practices of the Rhodesian CIO along with PSYOPS. CIO's and PSYOPS' use of anthrax would have been consistent with three other practices: 1) it would continue the PSYOPS operation of continuing psychological warfare on rural blacks by highlighting the fact that foreign diseases were the result of the guerillas; 2) CIO was already seeking to deny food supplies to the guerillas in line with "Operation Turkey,"197 and finally; 3) CIO would have been attracted to a weapon of last resort to break the morale of the rural blacks. To understand CIO's thinking, one must look at Zimbabwe at the time. As in other parts of Southern Africa, wealth is primarily measured by the number of cattle one has. ${ }^{198}$ Therefore, without cattle to measure their wealth, rural blacks' morale would sink and support for the uprising would end. For example:

188. GODWIN \& HANCOCK, supra note 104, at 99.

189. See Nass, supra note 168; see also CILLIERS, supra note 69, at 238.

190. See CILLERS, supra note 69, at 141.

191. See id. at 239.

192. See Nass, supra note 168.

193. See id.

194. See id.

195. See Taper Knox Chitiyo, Land Violence and Compensation: Reconceptualising Zimbabwe's Land And War Veteran's Debate, TRACK Two, Vol. 9 No. 1, May 2000, at http://ccrweb.ccc.uct.ac.za/two/9_1/zimbabwe.html (last visited Mar. 23, 2003).

196. See id.

197. See CILLIERS, supra note 69, at 158-59.

198. See Nass, supra note 168. 
There is always hardship, but if cattle die, the family loses its source of wealth; without motive power for ploughing [sic], crops cannot be planted, leading to no food, no money to purchase food, pay school fees, bus fares, taxes, or buy the essentials to life. The family is reduced to grinding poverty and malnutrition becomes rife. ${ }^{199}$

The use of the Selous Scouts furthered this goal. By imitating the guerillas, former officers have retold how massacres were perpetrated. Thus, the rural population would feel threatened by the guerillas. The land allocated to the Zimbabweans was mostly arid, whereas the white areas were relatively fertile. The alkalinity in the soil and the arid conditions would be ideal for the spread of anthrax. ${ }^{200}$ Nass suggests that aerial spraying is one possibility. ${ }^{201}$ As in other third world insurgencies, the Rhodesians built special protected villages into which the native population was concentrated, mostly involuntarily. ${ }^{202}$ Congregation of the rural population into one area could have contributed to the ease of intentional infestation by the Security Forces. ${ }^{203}$ This goal would meet the first prong of their desired use.

The second reason CIO and PSYOPS would use anthrax was that by destroying food stocks in rural areas, the original goals of "Operation Turkey" would be enhanced. Food was used as a weapon in Rhodesia. ${ }^{204}$ Therefore, it is conceivable that the anthrax program was meant to destroy Shona wealth and food processing. By denying the guerillas food, their morale would sink as their supply lines would be unable to support them. This was especially true as the SAS was simultaneously hitting targets outside Rhodesia. The CIO hoped the guerillas would merely starve in the field.

Finally, the CIO and PSYOPS knew that by 1978 the war was unwinnable. The Security Forces could not be beat, as they had won each battle, but neither could they win the war. In addition, the constant call-up of the male population was increasing emigration. ${ }^{205}$ Most knew that concentrated efforts to end the war had failed. ${ }^{206}$ The enemy was seen to be the villager as well. As shown earlier, post-1975, the CIO and Selous Scouts used untraditional means of warfare. Their operations were always along the line of reducing rural support for black nationalists and lowering morale. To that end, cholera was spread, thallium was used to poison people, and water supplies were poisoned. ${ }^{207}$ An interesting analysis is that of the main

199. Id.

200. See id.

201. See id.

202. See id.

203. See id.

204. See CILLIERS, supra note 69, at 158-59.

205. See NEWSBIT \& COWDEROY, supra note 7, at 101.

206. See id.

207. See Nass, supra note 168. 
operational area during the war-the Hurricane Theatre. Here, there were numerous "no go" or frozen areas because of Selous Scout activity in the border area at the time. ${ }^{208}$ It is plausible, that together with legitimate military operations, the Scouts were engaged in spreading anthrax. For example, as noted previously, the Selous Scouts were instructed to pour cholera agents in the Ruya River. ${ }^{209}$ Starting in August of 1973 "Exercise Long Walk" was begun along the Ruya River near Mozambique. ${ }^{210}$ Selous Scouts were active in the area and other Security Forces were told to pull out when the Scouts neared their positions. ${ }^{211}$ Henceforth, Security Forces were instructed not to approach the frozen zone and to stay at least 4000 meters from the Ruya River. $^{212}$ In 1978, in Mozambique large numbers of ZANLA soldiers arrived from training bases near the border with a bleeding disorder. ${ }^{213}$ At first, a hemorrhagic fever was suspected, but lab results showed warfarin poisoning. ${ }^{214}$

The first case of anthrax in humans was reported in November 1978, according to Nass. ${ }^{215}$ This is one month after the Rhodesian invasions and bombings of Mozambique and Zambia-the height of the war. Therefore, the outbreak would have coincided directly with a peak in hostilities. The use of anthrax could have strengthened the hand of the whites in the negotiating table illustrating that the black population was enduring the worst consequences of the war, and thus had the most to gain through a negotiated settlement. It was classic bargaining from strength of position.

The evidence shows that Rhodesia had a small indigenous bacteriological and chemical program by 1975 led by Dr. Symington under the supervision of the CIO. ${ }^{216}$ Anthrax is obtained by lab specimens or through collection of spores in the soil. ${ }^{217}$ As noted, the Rhodesians became experts at sanctions busting, with false end certificates, dummy companies, and fake airlines. ${ }^{218}$ The RhAF set up dummy corporations such as Air Gabon in Gabon, CargOman in Oman, and Air Trans Africa. ${ }^{219}$ Therefore, it is not to hard to imagine that Rhodesians could have obtained a batch of British anthrax spores from sympathetic admirers in Britain or through American labs. ${ }^{20}$

208. See id. Nass suggests that there might be a correlation to the no-go areas and the use of Anthrax by the Selous Scouts. See id. See also DALY, supra note 85, at 29.

209. See GODWIN \& HANCOCK, supra note 104, at 8.

210. See also DALY, supra note 85, at 29.

211. See id.

212. See id. at 41.

213. See Nass, supra note 168.

214. See id.

215. See id.

216. See MANGOLD \& GOLDBERG, supra note 119, at 223-26.

217. See Nass, supra note 168.

218. See NEWSBIT \& COWDEROY, supra note 7, at 56-65.

219. See id.

220. See Nass, supra note 168 ; see also MANGOLD \& GOLDBERG, supra note 119 , at 218 19. 
Britain experimented with anthrax during the Second World War. ${ }^{221}$ Anthrax does occur naturally in Zimbabwe, but not in sufficient quantities to justify the expense of field cultivation of spores. ${ }^{222}$ Discounting the evidence and dismissing the ingenuity of the Rhodesians for sanctions busting, the main culprit in the proliferation of bacteriological weapons to Rhodesia was most likely South Africa. ${ }^{223}$

\section{The South African Connection}

The main culprit for the Rhodesians obtaining biological weapons has been South Africa. ${ }^{224}$ South Africa was an original signatory to the Biological Weapons Convention in 1972, ratifying it November 5, 1975.25 South Africa has always maintained that its biological weapons program was solely for defensive use. ${ }^{226}$ South Africa produced chemical weapons during World War II in Gauteng-responsible for mustard gas production-for the Allies. ${ }^{227}$ South Africa claimed that undelivered stocks were destroyed after the war. ${ }^{228}$ However, former Allied production sites continued to be used by the South Africans for military purposes. ${ }^{229}$ To manufacture anthrax under 'ideal' conditions, high-containment suites are used. ${ }^{230}$ However, such facilities were not available to the Allies during World War Two, according to Nass. ${ }^{2.11}$

In 1968, South Africa provided Rhodesia with military support by sending a small contingent to Rhodesia to help with the insurgency. ${ }^{232}$ Nonetheless, to see both as an inseparable alliance of white supremacists is somewhat misleading. In 1975, South Africa pulled out most of its military assistance to Rhodesia. ${ }^{233}$ If South Africa assisted in the use of bacteriological weapons in Rhodesia, it was most likely for its own personal gain in research, rather than benevolent love. South Africa and Rhodesia were quite dissimilar with their one unifying aspect being continuation of white minority rule. South Africa was willing to sell out Rhodesia in order to appease the international community and buy time for their own Apartheid state. ${ }^{2.34}$ However, one major piece exculpating the South Africans from involvement has been the Truth and Reconciliation Commission's findings into the South

221. See Nass, supra note 168; see also MANGOLD \& GoLDBERG, supra note 119, at 219.

222. See id.

223. See MANGOLD \& GolDBERG, supra note 119, at 220.

224. See id.

225. See Chemical \& Biological Warfare, supra note 145.

226. See Nass, supra note 168.

227. See id.

228. See id.

229. See id.

230. See id.

231. See id.

232. See ClLLIERS, supra note 69 , at 9 .

233. See id. at 24.

234. See SMITH, supra note 30, at 232. 
African Project Coast. ${ }^{235}$ Project Coast may have commenced in the late 1970s to early 1980s, with an exact date unknown. ${ }^{236}$ What is known, is that by 1981 the head of 'Project Coast,' Dr. Basson-also known as Dr. Death-visited the U.S., meeting with CBW scientists. ${ }^{237}$ Project Coast experimented with cholera, botulism, anthrax, chemical poisoning, and lethal microorganisms. ${ }^{238}$ The military is alleged to have used cholera-as in Rhodesia-to poison wells, placed anthrax in cigarettes, and placed paraoxon in whiskey and then distributed it. ${ }^{239}$ However, there is no mention of South African and Rhodesian collusion. Yet, former $\mathrm{CIO}$ members have indicated that the South Africans bank rolled the Selous Scouts and had unfettered access to their Mount Darwin base. ${ }^{240}$ Nonetheless, the methods and choice of weapons used would lead to an inference that at least there was communication on shared technology and application at the operational level. ${ }^{241}$ In addition, South Africa launched "Operation Winter" whereby large assets of the Rhodesian military left Rhodesia upon majority rule. ${ }^{242}$ In some cases, whole units of the Selous Scouts and SAS joined the South African Defense Force, along with Rhodesia's dirty little tricks. ${ }^{243}$

\section{LEGAL ANALYSIS}

The main legal questions are: a) who should be held responsible; b) under what mechanisms; and c) should the state of Rhodesia be held liable or should the perpetrators?

\section{A. Analysis of Rhodesia as a State}

Because of Rhodesia's UDI its standing as a 'state' is paramount. The definition of what constitutes a state is well defined in international law. Under international law a state is an entity that has: a) defined territory; b) permanent population, under the control of its government; and c) capacity to

235. See Revenge of South Africa's Dr. Death, BBC News, available at http://news.bbc.co.uk/1/hi/world/africa/1920112.stm (last visited Jan. 12, 2003).

236. See Dr. Death Implicates West, BBC News, available at http://news.bbc.co.uk/2/hi/ world/africa/143006.stm (last visited Jan. 10, 2003) [hereinafter Dr. Death].

237. See Special Investigation into Project Coast, "South Africa's Chemical and Biological Warfare Programme," available at http://www.polity.org.za/govdocs/commissions/1998/trc/ 2chap6c.htm (last visited Jan. 10, 2003) [hereinafter Special Investigation]; see also, Dr. Death, supra note 236.

238. See Special Investigation, supra note 237.

239. See id.

240. See Brickhill, supra note 88 , at 10.

241. See id. at 8.

242. See id. at 59.

243. See id. 
engage in formal relations with other states. ${ }^{244}$ Meeting those requirements, an entity is a state whether or not it has been recognized by other states. ${ }^{245}$ However, there is a crucial distinction between state and government. A government, no matter how violent or wrongful in its origin, is a de facto government if it was in the "actual exercise of sovereignty over a territory and peoples large enough to be a nation." 246 De facto can be compared to de jure recognition, where the government is lawfully in power even though it exercises little actual power, for example an exiled govemment. ${ }^{247}$ Rhodesia at UDI had all the requirements of a state and its government was therefore, the de facto ruler of the country.

If Rhodesia was a state and de facto government, then are the various treaties outlawing the use of bacteriological/chemical weapons applicable to it? For humanitarian international law to apply there must be an internal or external armed conflict. ${ }^{248}$ Armed conflict exists when states resort to force, protracted armed violence between governmental authorities and organized groups, or between such groups within a state. ${ }^{249}$ Rhodesia was in a period of armed conflict from 1965 to 1980 , therefore, international humanitarian law applies.

The first attempt to deal with chemical weapons was the Hague's series of Conventions codifying the law of war, which entered into force in $1910 .^{250}$ Rhodesia may have violated the 1907 Hague Convention. Through Article 1, the convention is applicable to members of the Rhodesian Security Forces. ${ }^{251}$ Article 23(a) prohibits the use of "poison or poisoned weapons."252 The use of cholera, thallium, and other bacteriological agents is a clear violation of this article. The use of bacteriological weapons was outlawed by the 1925 Geneva Protocol, ${ }^{253}$ of which the United Kingdom is a party. In 1949, the Geneva Convention broadened the applicability of the treaty by adopting the phrase "armed conflict," replacing the narrower phrase of "laws or customs of war,"

244. See Kadic v. Karadzic, 70 F.3d 232, 244 (2d Cir. 1995), reh'g denied, (citing the RESTATEMENT (THIRD) OF FOREIGN RELATIONS \$ 201); accord Klinghoffer v. S.N.C. Achille Lauro, 937 F.2d 44, 47 (2d Cir. 1991); see also Montevideo Convention of 1933.

245. See RESTATEMENT (THIRD) OF FOREIGN RELATIONS $\$ 202 \mathrm{cmt}$. B

246. Ford v. Surget, 97 U.S. 594, 620 (1878), (Clifford, J., concurring).

247. See BLACK'S LAW DICTIONARY 697 (6th ed. 1990).

248. See The Prosecutor v. Dusko Tadic, Case no: IT-94-1-AR72, Appeals Chamber, Oct. 2, 1995; Int'l Crim. Trib. Yugo 1995.

249. See id.

250. Convention (IV) Respecting the Laws and Customs of War on Land and its Annex: Regulation Concerning the Laws and Customs of War on Land, Oct. 18, 1907, 36 Stat. 2277 ,

1 Bevans 631 [hereinafter 1907 Hague Convention].

251. See id. art. 1.

252. See id. art. 23(a).

253. Protocol for the Prohibition of the Use in War Asphyxiating. Poisonous or Other Gases, and of Bacteriological Methods of Warfare, June 17, 1925, U.S.T. 571, 94 L.N.T.S. 65 [hereinafter 1925 Geneva Convention]. 
as used in the 1907 Hague and 1925 Geneva Convention. ${ }^{254}$ The 1949 Geneva Convention was built upon the prior treaties which have been universally applied. ${ }^{255}$

Under Article III of the Geneva Conventions, which makes itself applicable to internal conflicts and civil wars, Rhodesia committed several "grave breaches." By killing cattle, the Rhodesian Security Forces targeted the wealth of the rural population, a violation of Article III(1). Furthermore, the Selous Scouts killed, captured insurgents, or used them for biological experimentation if they did not "turn." 256 These practices are a violation of Article III(1)(a). ${ }^{257}$ Great Britain was a signatory to the Geneva Convention, however Rhodesia was not. Nonetheless, international law and recent cases have elevated Article III of the Geneva Convention to customary law. ${ }^{258} \mathrm{~A}$ violation of the Article is a violation of customary law.

In addition to these two treaties, there is the 1972 Biological Weapons Convention (BWC) which renounces the use of biological weapons against human beings. ${ }^{259}$ The BWC reflects the post-World War II renunciation of biological weapons by the defeated Axis powers and the unilateral renunciation of the use of such weapons by the U.S. in 1969. ${ }^{260}$ By enlarging the scope of the 1949 Geneva Convention, through Article III, the use of chemical weapons in internal armed conflicts is outlawed. ${ }^{261}$ With its declaration of UDI, it is arguable whether the use of these weapons would have been 'illegal' under the Geneva Protocol since Rhodesia was never a party to the Convention, which bans the use and possession of biological weapons. Furthermore, Rhodesia's independence was illegal and not recognized by the international community. ${ }^{262}$ Nevertheless, the use of such weapons has risen to a violation of customary international law. For a practice to become customary international law there must emerge a general consensus in the international community that furthering the practice violates international customary law.

254. See 1907 Hague Convention, supra note 250; see also 1925 Geneva Convention, supra note 253.

255. Convention (IV) Relative to the Protection of Civilian Persons in Time of War, Aug. 12, 1949, 6 U.S.T. 3516, 73 U.N.T.S. 287 (entered into force Oct. 21, 1950)[hereinafter 1949 Geneva Convention].

256. See ClLLIERS, supra note 69, at 33.

257. See 1949 Geneva Convention, supra note 255.

258. See generally Theodorc Meron, The Geneva Conventions as Customary Law, 81 AM. J. INT'L L. 348 (1987).

259. Convention on Prohibition of Development, Production, and Stockpiling of Bacteriological (Biological) and Toxin Weapons and on Their Destruction, Aug. 10, 1972, 86 U.S.T. 583, 1015 U.N.T.S. 163 [hereinafter 1972 Biological Weapons Convention].

260. Michael Moodie, Agents of Death, Forum for Applied Research \& Public Policy, Vol. 15, Issue 1, Apr. 1, 2001.

261. See 1949 Geneva Convention, supra note 255.

262. U.N. Sec. Council Res., Res. 217, UNSCOR, 20th Sess., 1265th mtg., UN Doc S/RES/217, II 8. 
In 1988, Iraq used chemical weapons in an internal conflict. ${ }^{263}$ International condemnations of the use of chemical weapons against an internal civilian population were swift, accusing Iraq of violating the 1925 Geneva Convention. ${ }^{264}$ Therefore, under the Hague Convention and 1925 Geneva Protocol the use of chemical or biological weapons against internal populations has been raised to a violation of customary humanitarian law.

The successor to Rhodesia through decolonization is Zimbabwe. ${ }^{265}$ Under the Vienna Convention a newly independent state begins its existence free of the obligations of its predecessor state, the 'clean slate doctrine. ${ }^{266}$ At independence the United Kingdom attempted a legal fiction. It turned back Zimbabwe's clock to 1965 by appointing a Governor and reincorporating Zimbabwe into the Commonwealth of States, the successor to the British Empire. The illegality of the regime was overturned and Zimbabwe emerged as a new nation under the clean slate doctrine. Therefore, since violation of the treaties is a violation of international customary law Zimbabwe is liable for violations by Rhodesian security forces. This is a non-sequitor, and thus illogical. Therefore, one must turn to the next logical question if the state is not responsible, are the perpetrators and under what judicial model can they be brought to justice?

\section{B. Holding Individuals Accountable}

The law of nations does not confine its reach to state actions. ${ }^{267}$ There are innumerable references to individuals committing an offense against the law of nations. ${ }^{268}$ Therefore, individuals who were part of the Rhodesian Security forces who violated international customary law during the internal armed conflict of 1965-80 should be prosecuted. For example, Symington's experiments on humans are a clear crime against humanity. ${ }^{269}$ The question

263. Christopher Clarke Psoteraro, Intervention in Iraq: Towards a Doctrine of Anticipatory Counter-Terrorism, Counter-Proliferation Intervention, 15 FLA. J. INT'L L. 151 (2002).

264. U.S. DePartment of STate, Press Guidance, Sept. 9, 1988.

Questions have been raised as to whether the prohibition in the 1925 Geneva Protocol against chemical weapons use 'in war' applies to use in internal conflicts. It is clear that such use against civilian population would be contrary to the customary international law that is applicable to internal armed conflicts, Id. as well as other international agreements.

265. Revi Nossman, Existence Tenuous for White Africans, NEW ORLEANS TIMESPICAYUNE, June 18, 2000, available at 2000 WL 21265452.

266. See Vienna Convention on the Law of Treaties, arts. 17, 24, 1153 U.N.T.S. 331, 8 I.L.M. 679 (1969); see also International Military Tribunal (Nuremberg) Judgment and Sentences 41 A.J.I.L. 220-21 (1946) [hereinafter International Military Tribunal].

267. See Karadzic, 70 F.3d at 238.

268. See, e.g., U.S. v. Smith, 18 U.S. 153, 161-62 (1820).

269. See International Military Tribunal, supra note 266. 
now turns to what forum: a Nuremberg-style court, a domestic court, or a foreign court that may have jurisdiction.

Under international law, the Rhodesian Security Forces committed two major international crimes: 1) war crimes, and 2) grave breaches of the Geneva Conventions. ${ }^{270}$ War crimes-violations of the customs of war, i.e. Hague 1907-include: murder or ill treatment of prisoners of war, wanton destruction, use of biological agents, and devastation not justified by military necessity. ${ }^{271}$ The grave breaches include: willful killing, biological experiments, compelling a prisoner of war to serve in forces of a hostile power, making the civilian population targets of attack, racial discrimination, deportation of population of occupied territory, and willfully causing great suffering or serious injury to body and health. ${ }^{272}$ If a Nuremberg style court is established, which is doubtful because of the time lapse in the events, criminal prosecution can take place against those members of the Security Forces who perpetuated the crimes and their leaders who authorized the use of these tactics. ${ }^{273}$

The principles of the Nuremberg International Military Tribunal provides for individual criminal responsibility for war crimes. ${ }^{274}$ Leaders and organizers participating in the formulation or execution of a common plan for war crimes and grave breaches are vicariously responsible for all acts performed by any persons in execution of such plan. ${ }^{275}$ Even if a commander did not participate, he may be responsible for the actions of his troops if he knew about the atrocities and did nothing to stop them. ${ }^{276}$ Although feasible, a Nuremberg style court, modeled perhaps on the International Criminal Tribunals for the former Yugoslavia and Rwanda are impractical. First, since the accused acted under color of state action and not individually, they are not hostis humani generis, enemies of all mankind. ${ }^{277}$ Although because of the violations, universal jurisdiction may be allowed, and hence, the concept of aut dedere aut judicar (extradite or prosecute) comes into play. ${ }^{278}$ Nonetheless,

270. Protocol Additional to the Geneva Convention of 12 August 1949 and Relating to Protection of Victims of International Armed Conflicts (Protocol 1), 1125 U.N.T.S. 3 (entered into force Dec. 7, 1998). Protocol One applies also because it applies to, "armed conflicts in which peoples are fighting against colonial domination and alien occupation and against racist regimes in the exercise of their right to self-determination, as enshrined in the Charter of the United Nations ...." Id.

271. See id. art. $85(5)$.

272. See id. art. 85(3)(a-f).

273. Ken Flower, the head of CIO died in 1987. See GoDWIN \& HANCOCK, supra note 104 , at 76.

274. See George A. Finch, The Nuremburg Trial and International Law, 41 AM. J. INT'L L. 20,20 (1947).

275. See In re Yamashita, 327 U.S. 1, 15 (1946).

276. See id.

277. See William Blackstone, IV COMMENTARIES ON THE LaWS OF ENGLAND 71 (University of Chicago Press ed., 1979)(1765).

278. See generally M. CHERIF BASSIOUNI \& EDWARD M. WISE, AUT DEDERE AUT JUDICARE: THE DUTY TO EXTRADITE OR PROSECUTE IN INTERNATIONAL LAW (2001). 
nation states may be hesitant to occupy themselves with matters that occurred nearly twenty years ago. The international community is too preoccupied with other African conflicts, namely Sierra Leone-the crisis de jure-to contemplate setting up another African tribunal. Nation states might also be sympathetic to the 'losers,' many of whom did lose their livelihoods and property. Secondly, members of the Rhodesian security services are unlikely to testify against each other because many received amnesty for their acts under the Lancaster agreement. In addition, as in all armed services, a code of silence develops in the fogs of war. Finally, that leaves either domestic remedies for the victims or foreign courts.

\section{Forum Choices}

Perhaps the first outside confirmation came in 1990 from a Defense Intelligence Agency Cable from Harare to Washington, "[a]ccording to [source deleted], a member of the Rhodesian Selous Scouts admitted in 1978 that 'they' had tried both chemical and biological warfare techniques to kill terrorists."279 The report went on to say that Rhodesian forces used cholera to poison the water supply. ${ }^{280}$ It appears that Washington was, and still is, oblivious to the use of bacteriological weapons in Zimbabwe. ${ }^{281}$ Nonetheless, officials of the U.S. Embassy in Harare seem aware of the situation, but dubious as to its credibility. ${ }^{282}$

In 1997, the Minister of Health Tim Stamps-a white Zimbabweanpersonally ordered an official investigation into the use of bacteriological agents in the Liberation War. ${ }^{283}$ Stamps is convinced that through forged documents, the U.S. or U.K., shipped anthrax for legitimate research in a third country, but it eventually wound up in Rhodesia. ${ }^{284}$ Stamps is convinced that the spread of the disease was deliberate. ${ }^{285}$ He points out that the Africans were severely restricted in their movements, the focus of the outbreak being so widespread and the targeting of cattle in particular. ${ }^{286}$

In 1999 , a call was made by university professors to the government of Zimbabwe to investigate the 1975-80 incidents of bacteriological war, in part because of Stamps' insistence. ${ }^{287}$ Yet, to date nothing has been officially

279. See MANGOLD \& GOLDBERG, supra note 119, at 218.

280. See id.

281. Telephone Interview with State Department Desk Officer, Miami FL(Nov. 14, 2001) (on file with author).

282. E-mail Interview with Author's confidential source, Miami, FL (Nov. 15, 2001) (on file with author).

283. See MANGOLD \& GOLDBERG, supra note 119, at 218.

284. See id.

285. See id. at 218-19.

286. See id. at 19.

287. See Zimbabwe: Government Urged to Probe Reports Citing Use of Chemical Agents, AFriCA News SERVICE, Nov. 12, 1999. 
undertaken by the government of Zimbabwe. The reasons for not acting against the report are twofold. One, the white population in Zimbabwe fell from around 190,000 in 1980 , to 90,000 in $2000 .{ }^{288}$ They were the economic backbone of the country. ${ }^{289}$ To his credit, Mugabe tried to build a multi-racial country. ${ }^{290}$ Reconciliation was the tone. The whites were allowed to stay as long as they knew their place in the new country.

During the 1990s, Mugabe faced several problems to his rule. In 1990 there were fewer jobs for blacks than there were in 1975 and real incomes were down from what they were in $1975 .^{291}$ In an attempt to escape domestic problems, Mugabe turned to the legacy of land distribution in Zimbabwe. In 2000 , farm invasions began as the government attempted to illegally seize white farms. ${ }^{292}$ White emigration began again and in 2001, the white population was less than 50,000 consisting mostly of retired persons. ${ }^{293}$ Mugabe-through his ministers-keeps the specter of whites being allpowerful and treacherous. Nonetheless, he cannot institute an inquiry because it just might show that anthrax was not used in the conflict or worse yet, that Mugabe and his side might have done their own dirty tricks. Mugabe and his ministers recently insinuated that the remaining whites may use anthrax again against the black government. ${ }^{294}$ On October 25,2001 , the Deputy Health Minister said that exiled Rhodesians and white Zimbabweans were preparing an anthrax attack. ${ }^{295}$ The state controlled media the same week interviewed rural farmers in a recent anthrax outbreak. The rural farmers claim that the remaining white commercial farmers have activated the anthrax used in the liberation war. ${ }^{296}$ In January 2002, the government orchestrated an 'anthrax scare' and blamed it on the opposition political party and white farmers-one of their supporters. ${ }^{297}$ However, these inquiries were quickly suppressed:

ZANLA and/or ZIPRA may also have had complicity in spreading the biotoxins around. The war between ZANLA

288. See A Socialist Confronts Poverty With a Wealth of Pragmatism, WASH. TIMES, Nov. 5, 1990. The White Population was 125,000 in 1990; 90,000 in 1991.

289. See Zimbabwe's 'Bush Peace' Deadly to White Farmers, WASH. PosT, Mar. 8, 1988 ([i]n 1988 whites held all but twelve of the top 200 executive positions in Zimbabwe's 100 largest companies); see also Alienated from Africa, AFRICA REPORT, Feb. 1991.

290. See Alienated from Africa, AFRICA REPORT, Feb. 1991.

291. See BBCNEws, Zimbabwe's Anthrax 'Gimmick, 'available at http://news.bbc.co.uk/ $\mathrm{hi} /$ english/world/africa/newsid_1752000/1752767.stm (last visited Jan. 10, 2002).

292. See Zimbabwe Tells Britain to Compensate White Farmers, Guardian Unlimited, Apr. 7, 2002, available at http://www.guardian.co.uk/zimbabwe/article/0,763,181 149,00.html (last visited Jan. 10, 2003).

293. Samson Mulgata, Sowing Uncertainty: Zimbabwe's Seizure of White Farmland Hurts Black Workers Too, Newsday, Oct. 6, 2002, available at 2002 WL 101394914.

294. See Zimbabwe Prepared for Anthrax Attacks, PANAFRICAN NEwS AGENCY, Oct. 25, 2001.

295. See id.

296. See id.

297. See BBC NEWS, supra note 291. 
and ZIPRA, was by far the deadliest and most destructive aspect of the liberation struggle. ZANLA was fighting ZIPRA as much as it was the Rhodesian Army. ZANLA may have become aware of the Rhodesians' bio 'dirty tricks' and used them, such as the poisoned food tins, against villages sympathetic to ZIPRA, possibly even with the Rhodesians' help. Or, ZIPRA may have done the same to ZANLA, but I think the former is more likely. I think this is a more logical explanation for why a more comprehensive investigation has never been undertaken. In the current environment, this is the perfect story to vilify the remaining whites in Zimbabwe and justify seizing their property. The GOZ [government of Zimbabwe] would only have to go after a handful to make the case that its campaign against the whites was part of the war on terrorism, and this, in turn, could give the West pause in vilifying the GOZ (I don't think it would lead to a mass white exodus, however). Instead, the 'story' that the whites were planning an anthrax attack, and the 'story' about anthrax-like substances turning up at the central post office disappeared quickly. I suspect someone on high squashed any further investigations because of where it might lead. ${ }^{298}$

In conclusion, domestic remedies against those remaining Security Forces personnel would be highly unlikely under the Mugabe regime and his co-opted justice system. If the trials were to show that there was no use of chemical/biological weapons, Mugabe would be unable to continue to use whites as scapegoats. If whites are found to be guilty of the use of these weapons, the stigma attached could well produce the final exodus of whites in the country, plunging it into complete economic chaos.

Therefore, the last and the most feasible option for those affected during the liberation war is to use the forum of a third country whose laws would allow an alien to seek compensation for damages, like the United States or Belgium. In the United States, Zimbabweans may use the Alien Tort Claim Act, 28 U.S.C. $\S 1350$ (1988), enacted in 1789 which creates federal court jurisdiction for suits alleging torts committed anywhere in the world against aliens in violation of the law of nations. ${ }^{299}$ In addition, federal common law has incorporated international customary law. ${ }^{300}$ Therefore, an alien within the U.S. can pursue a claim against the former Rhodesian Security Forces. In fact, on September 9, 2000, Zimbabweans living in the U.S. filed suit against

298. E-mail Interview with Author's confidential source, Miami, FL Apr. 16, 2002 (on file with author).

299. See Filartiga v. Pena-Irala, 630 F.2d 876 (2d Cir. 1980).

300. See The Paquete Habana, 175 U.S. 677, 700 (1900), 
Mugabe and two of his associates under the Alien Tort Act for torturing their relative in Zimbabwe because they belonged to another party. ${ }^{301}$

Another venue that would accept alien tort lawsuits is Belgium with its far reaching war crimes law. ${ }^{302}$ The 1993 Belgian law gives the country's courts "universal jurisdiction" for crimes against humanity. ${ }^{303}$ In October 2001, Cuban exiles in Miami filed suit against Fidel Castro in Belgium's courts under the law. ${ }^{304}$ Abuse of the law has created embarrassment for Belgians who seek to limit the powers of the law to reduce lawsuits. ${ }^{305}$ Nonetheless, like the U.S. Alien Tort Act, this Belgian law also gives Zimbabweans a ready option for their grievances.

\section{South African Actors-Exempt.}

If South Africa used bacteriological weapons, it was in violation of Article II of the Convention. If it possessed and developed, along with Rhodesia, bacteriological agents such as cholera and thallium, then it was in violation of Article I of the Convention. If South Africa helped proliferate the spread by helping Rhodesia acquire the technology and the means to use those weapons, it is also in violation of Article III of the Convention. Rather than stop or prevent the development of these weapons domestically, South Africa actively participated in their development in violation of Article IV of the Convention. ${ }^{306}$ Under the Convention's Article VI, only state parties to the Convention may lodge alleged violations. ${ }^{307}$ To date none has. Nonetheless, domestically, under the Truth and Reconciliation Commission, crimes committed under Apartheid may be pardoned if the perpetrators testify about their crimes. Many in the biological program did and were subsequently pardoned. ${ }^{308}$ However, South Africa's 'Project Coast' is still a state secret and its machinations are under "lock and key." ${ }^{309}$ A court conducted in Afrikaans, whose main witnesses were throw backs to the 1970s defense establishment, recently found even Dr. Basson, ('Dr. Death')-who did not repent-not

301. See Mugabe Sued in New York Over Rights Abuses, WASH. Post, Sept. 9, 2000, at A3.

302. See Kamer keurt aangepaste genocidewet gocd, DE STANDARD ONLINE, available at http://www.standaard.be/Misc./print.asp?articleID=NFLA02042003_001 (last visited Apr. 3, 2003).

303. See id.

304. See Exiles Seek Castro's Indictment in Belgium, WASH. POST, Oct. 4, 2001, at A32.

305. See Belgium 'Embarrassed' by Probe of Sharon, WASH. POST, July 6, 2001, at A18.

306. See 1949 Convention, supra note 255 , art. III.

307. See id. art. IV.

308. Urged to Speed Up TRC Reparations, SAPA, Aug. 14, 2002, available at $2002 \mathrm{WL}$ 23698917.

309. Dr. Death, supra note 236. 
guilty. ${ }^{310}$ In addition, South Africa was not a belligerent under Article I of the 1907 Hague Convention. ${ }^{311}$

\section{CONCLUSION}

Through practice, a custom can emerge. Most countries have forsaken the use of bacteriological agents. Therefore, it can be argued that the use of bacteriological weapons by Rhodesians in 1975-80 was a violation of the 1907 Hague Convention, regardless of Rhodesia's international status and Article III of the 1949 Geneva Convention, regardless of its status as an 'illegal' state, since individual responsibility can be used. Therefore, the Rhodesian Security Forces can be prosecuted for War Crimes, although a proper venue will be difficult to find. If the current government is unwilling to put forward claims against the prior regime, then ordinary citizens who were affected can bring forth claims. Since Zimbabwe has descended into a one party dictatorship, Zimbabweans may have to look abroad for a judicial solution to the crimes committed against them.

310. Revenge of South Africa's Dr. Death, BBC NEWS, available at http://news.bbc.co.uk/2/hi/world/africa/1926117.stm (last visited Aug. 8, 2002).

311. See 1907 Hague convention, supra note 250, art. I(1-4). 
